\title{
NATURAL ADDITIVES IN FUNCTIONAL EGG PRODUCTION
}

\author{
Nedeljka J. Spasevski* ${ }^{1}$, Tatjana A. Peulić ${ }^{1}$, Vojislav V. Banjac ${ }^{1}$, Slađana M. Rakita ${ }^{1}$, Lato L. Pezo ${ }^{2}$, \\ Radmilo R. Čolović ${ }^{1}$, Zorica N. Basić ${ }^{3}$ \\ ${ }^{1}$ University of Novi Sad, Institute of Food Technology, 21000 Novi Sad, Bulevar cara Lazara 1, Serbia \\ ${ }^{2}$ University of Belgrade, Institute of General and Physical Chemistry, 11158 Belgrade, \\ Studentski trg 12/V, Serbia \\ ${ }^{3}$ Military Medical Academy, Institute of Hygiene, 11040 Belgrade, Crnotravska 17, Serbia
}

\author{
*Corresponding author: \\ Phone: +381214853807 \\ Fax: +38121450725 \\ E-mail address: nedeljka.spasevski@fins.uns.ac.rs
}

\begin{abstract}
Table eggs can play an important role as functional food, especially if specially designed mixtures enriched with $\omega-3$ fatty acids, natural pigments and vitamins are used for their production. Thus, the aim of this study was to investigate the effects of inclusion of flax-corn meal co-extrudate (FCM) in combination with natural pigments in hens' diet on physical properties, yolk colour and fatty acid composition of eggs.

One hundred and twenty Lohmann Brown laying hens were fed corn-soybean meal based diet with the addition of FCM at different levels: $0 \%$ (control $\mathrm{C} 1$ and $\mathrm{C} 2$ ), $13.50 \%$ experimental treatment (E1) and $22.50 \%$ experimental treatment $(E 2)$. The control treatment $(C 1)$ contained up to $3 \%$ fat, without added pigments while the control treatment (C2) contained up to $5 \%$ fat and synthetic pigments. Experimental treatments E1 and E2 (3\% and 5\% fat, respectively) had the same amount of natural pigments ( $1 \%$ carrot and $0.5 \%$ paprika). When compared with control eggs, no significant changes $(p>0.05)$ in the egg quality characteristics were observed for E1 and E2 eggs. Desirable egg yolk colour of 12.78 RYCF (Roche Yolk Colour Fan scale) was achieved in the treatments E1 and E2. Eggs from hens fed FCM had significantly higher level $(p<0.001)$ of $\alpha$-linolenic $(6.46 \%$ for $E 1$ and $8.87 \%$ for E2), docosahexaenoic $(2.01 \%$ for E1 and $2.08 \%$ for E2) and eicosapentaenoic $(0.17 \%$ for E1 and $0.21 \%$ for E2) acids in comparison to eggs originated from hens fed control diets. The $\omega-6 / \omega-3$ ratios of 1.43 and 1.01 in the treatments $E 1$ and $E 2$, respectively, were significantly lower $(p<0.001)$ than $\omega-6 / \omega-3$ ratios in the control treatments $C 1$ and $C 2$ (9.40 and 8.88, respectively). The content of tocopherol in eggs from the experimental treatments E1 and E2 were 6 and 8 times higher than in eggs from the control treatment $\mathrm{C} 1$ as well as 1.8 and 2.3 times higher than in eggs from the control treatment $\mathrm{C2}$, respectively. By the addition of FCM and natural pigments in hens' diet, it is possible to produce functional egg with desirable colour and fatty acid composition.
\end{abstract}

Key words: flax-corn meal co-extrudate, carrot, paprika, polyunsaturated fatty acids, $\omega-6 / \omega-3$ ratio, tocopherols

\section{INTRODUCTION}

Nowadays there are numerous scientific research related to food and its health benefits, as well as relation between consumption of some functional food and the reduction of the risk of serious chronic diseases. According to definition, the term functional food is described as food which contains active compounds that further have positive influence on physiological processes in organism and beneficial effects on human health. The functional food has to contain higher amount of some compounds, which positively influence human health. In the case where it isn't naturally contained in sufficient amount, functional food must be further enriched with 
these compounds. Since ancient time, eggs have been considered as very valuable food source, which is, due to its low price, worldwide consumed and available. Nutritive profile of eggs can be easily enriched with omega-3 polyunsaturated fatty acid ( $\omega-3$, PUFA), minerals and vitamins by addition of these compounds in laying hen diet.

During the last few years, many studies have shown that some specific compounds that have positive health influence could be transported from laying hen diet to yolk (Bean and Leeson, 2003; Khan et al. 2012) and increase in human nutrition as well. This is of high interests, since omega-3 PUFA of long chain have shown variable positive effects including prevention of cardiovascular diseases, arthritis and diabetes (Simopoulos, 2000; Wang et al. 2004). a-linolenic acid (ALA, C18: 3n3 ), eicosapentaenoic acid (EPA, C20: 5n3 ) and docosahexaenoic acid (DHA, C22: $6 n-3)$ are the most important $\omega-3$ PUFA. ALA is a very important fatty acid (FA), precursor for EPA and DHA synthesis, which cannot be synthesized in human body and the only way for its intake is through food (Whelan and Rust, 2006). Because of that this fatty acid is called essential and considering the small and insufficient synthesised amounts of EPA and DHA, these acids are called conditionally essential fatty acids and it is necessary to take it additionally through food. These compounds have multiple roles in the proper functioning of the human body. They are responsible for proper child brain development, resistance to different allergies, autoimmune disease, cardiovascular problems and inflammatory processes (Sierra et al., 2008).

One of the solutions to produce functional eggs is adding a flaxseed or its products in laying hens diet. Despite its high nutritional value, flaxseed is insufficiently used in animal feed production due to the presence of antinutritional factors, primarily cyanogenic glycosides (Htoo et al., 2008). Thermal processes that use heating with addition of water or steam such as pelleting, extruding, autoclaving and microwaving are mostly used for detoxification of flexseed (Htoo et al., 2008, Ivanov et al.,
2012). After thermal treatment, obtained product is sensitive to oxidation processes and polymerization. Therefore, in order to protect the product it is necessary to add antioxidants, vitamin $\mathrm{E}$ and different polyphenolic compounds (Tepe et al., 2005, Kulisić et al., 2004).

Although yolk colour has no influence on the taste of the egg or on the content of nutritional compounds, the yolk colour is one of the most important attributes of sensory quality, and many consumers rather prefer eggs with darker yolk colour. The yolk colour also depends on laying hen diet and it can be affected by carotenoid addition. Since higher amount of carotenoids have shown numerous positive influence on health, eggs are considered as foodstuff which is very suitable for the transfer of carotenoids in the human chain food (Skrivan and Englmaierova, 2014).

The main goal of the present study was to investigate the possibility of designing functional eggs by incorporating to hens' diet flaxseed products as a source of $\omega-3$ fatty acids and natural pigments as co-louring agents and to determine their effects on egg quality parameters and yolk colour.

\section{MATERIALS AND METHODS}

The feeding trial was conducted on 120 Lohmann Brown laying hens for one month. Hens were divided into four treatments ( 2 control and 2 experimental) with a total of thirty hens. The birds were housed in wire cages with feed and water available ad libitum. The samples were collected on $30^{\text {th }}$ day of the experiment.

The laying hens in control treatments were fed corn-soybean meal basal diet. In the first control treatment $\mathrm{C} 1$ (which contained up to $3 \%$ fat) pigments were not added, while the second control treatment $\mathrm{C} 2$ (with 5\% fat) contained synthetic pigments $(0.04 \mathrm{~g} / \mathrm{kg}$ carophyll red and $0.015 \mathrm{~g} / \mathrm{kg}$ carophyll yellow). In the first experimental treatment (E1) $13.50 \%$ of flax-corn meal co-extrudate (FCM) was added (3\% fat), while in the second experimental treatment (E2) $22.50 \%$ of FCM was added (5\% fat). In the both experimental treatment, total fat content originated from FCM. 
Table 1.

Composition of control and experimental diet and chemical analysis of the feed

\begin{tabular}{|c|c|c|c|c|}
\hline \multirow{2}{*}{ Ingredients (\%) } & \multicolumn{4}{|c|}{ Control and experimental diet } \\
\hline & C1 & C2 & E1 & E2 \\
\hline Corn & 57.60 & 55.40 & - & - \\
\hline Corn meal & - & - & 46.70 & 40.30 \\
\hline Co-extruded flaxseed & - & - & 13.50 & 22.50 \\
\hline Soybean meal & 20.00 & 20.00 & 17.20 & 14.60 \\
\hline Sunflower meal - 33\% protein & 8.50 & 9.00 & 8.50 & 8.50 \\
\hline Soybean oil & 1.30 & 3.00 & - & - \\
\hline Yeast & 2.00 & 2.00 & 2.00 & 2.00 \\
\hline Monocalcium phosphate & 1.20 & 1.20 & 1.20 & 1.20 \\
\hline Sodium bicarbonate & 0.10 & 0.10 & 0.10 & 0.10 \\
\hline Premix & 1.00 & 1.00 & 1.00 & 1.00 \\
\hline Limestone & 8.00 & 8.00 & 8.00 & 8.00 \\
\hline Salt & 0.30 & 0.30 & 0.30 & 0.30 \\
\hline Synthetic pigment ${ }^{\mathrm{a}}(\mathrm{g} / \mathrm{kg})$ & - & 0.06 & & \\
\hline Paprika & - & - & 0.50 & 0.50 \\
\hline Carrot & - & - & 1.00 & 1.00 \\
\hline \multicolumn{5}{|l|}{ Nutrient composition (\%) } \\
\hline Dry & 89.55 & 89.81 & 90.35 & 91.01 \\
\hline Crude protein & 15.87 & 15.93 & 16.07 & 15.98 \\
\hline Crude fat & 3.86 & 5.51 & 3.90 & 5.75 \\
\hline Crude ash & 11.56 & 11.26 & 11.67 & 11.14 \\
\hline Crude fibre & 5.69 & 6.17 & 4.63 & 5.11 \\
\hline Calcium & 3.53 & 3.64 & 3.56 & 3.67 \\
\hline Total phosphorus & 0.52 & 0.53 & 0.54 & 0.53 \\
\hline Metabolizable energy ${ }^{\mathrm{b}}(\mathrm{MJl} / \mathrm{kg})$ & 11.57 & 11.62 & 11.55 & 11.73 \\
\hline
\end{tabular}

${ }^{a}$ Control treatment C2 contains: $0.04 \mathrm{~g} / \mathrm{kg}$ carophyll red and $0.015 \mathrm{~g} / \mathrm{kg}$ carophyll yellow

${ }^{b}$ Metabolisable energy was calculated mathematically using software package PanonMix@2013designed for animal feed mixture formulation

With the addition of FCM in the amount of $13.50 \%$ and $22.50 \%$ in a final mixture, the content of vitamin $\mathrm{E}$ in treatment $\mathrm{E} 1$ and E2 was 224 and $372.4 \mathrm{mg}$ per $\mathrm{kg}$ of feed, respectively. The same amounts of natural source of pigments were added in both experimental treatments instead of synthetic pigments. Based on the preliminary results of the study by Spasevski et al. (2018), it was decided to use a combination of $1 \%$ carrot and $0.5 \%$ paprika. The composition and chemical analysis of control and experimental diets are presented in Table 1.

\section{Chemical analysis}

The content of moisture, crude protein, crude ash, crude fat, and crude fibre were determined according to AOAC (1998), methods 934.01; 978.04; 942.05: 920.39 and 978.10 , respectively.

\section{Fatty acid analysis}

The extraction of total lipids from egg yolk was conducted according to the method of Folch et al. (1957). Fatty acid methyl esters were prepared from total lipid extract using $14 \%$ methanol solution of bortrifluoride. Analysis of fatty acids in the samples was performed by gas chromategraphy on an Agilent 7890A system (Agilent Technologies, Santa Clara, CA, USA) as described by Spasevski et al. (2016). The GC regime was previously described by Čolović et al. (2015).

Analysis of total tocopherols in egg yolks After the saponification of samples with aqueous solution of $\mathrm{KOH}(3 \mathrm{~mL})$ and $95 \%$ ethanol $(20 \mathrm{~mL})$, total tocopherols from egg yolk were extracted with cold deionized water and hexane. The obtained samples were analysed by high pressure 
liquid chromatography (Waters M600E, USA). The HPLC regime was set according to Rabrenović et al. (2016).

Visual and instrumental methods for determination of yolk colour

The colour of the egg yolks was determined visually and instrumentally. Visual colour determination was carried out with the RYCF scale (Hoffmann-La Roche Ltd, Basel, Switzerland), where the colour values range from 15 (dark orange) to 1 (light pale). A Minolta Chroma Meter (Model CR-400, Minolta Co., Osaka, Japan) was used for instrumental measurement of yolk colour. The results are presented according to the CIELab colour system, where the colour values were expressed as $L^{*}$ (lightness), $a^{*}$ (redness/greenness) and $b^{*}$ (yellowness/blueness). The content of $\beta$-carotene was determined by the spectrophotometric method according to Spasevski et al. (2016). Acetone was used for extraction and the results were expressed as $\mu \mathrm{g}$ of $\beta$-carotene per $\mathrm{g}$ of the sample.

\section{Statistical analysis}

The results (mean \pm standard deviations) were expressed by one-way analysis of variance (ANOVA) using Statistics software version 13 (Statsoft Inc. 2013, USA). Significant differences among treatment means were analysed by Tukey's HSD tests. The data means were considered significant at $p<0.05$.

\section{RESULTS AND DISCUSSION}

Table 2 shows the influence of laying hens' nutrition during four weeks of feeding on the egg quality characteristics. It could be observed that the addition of coextruded flaxseed and natural pigments in laying hens' diet did not negatively affect the physical characteristics of the eggs, because no significant $(p>0.05)$ changes were obtained between eggs in control and experimental groups.

These results are in agreement with findings of others (Bean and Leeson, 2003, Ahmad et al., 2013, Cherian and Quezada, 2016) who reported that addition of flaxseed in laying hens' diet had no effect on egg performance and with Lokaewmanee et al. (2010) and Rowghani et al.
(2006) who reported no influence of paprika addition on egg quality properties. The influence of dietary FCM, carrot and paprika on egg yolk colour is presented in Table 3. After 30 days of feeding trial, the values obtained according to RYCF, $\beta$ carotene content and redness $\left(a^{*}\right)$ were significantly higher $(p<0.05)$ in both experimental treatments (E1 and E2) compared to control treatment $\mathrm{C} 1$, and signifycantly lower $(p<0.05)$ compared to control treatment C2 (except content of $\beta$-carotene). However, no changes in yellowness $\left(b^{*}\right)$ and lightness $\left(L^{*}\right)$ index were observed between the treatments. $\beta$-carotene content which was the highest in eggs from hens fed control treatment C2 (containing synthetic pigments) accounted to $55.15 \mu \mathrm{g} / \mathrm{g}$. This level of $\beta$-carotene was higher but not statistically significant $(p>0.05)$ than that following the experimental treatments E1 and E2. Similar results obtained in both experimental treatments indicated that colour of egg yolk did not depend on the addition of co-extruded flaxseed $(13.50 \%$ in $E 1 ; 22.50 \%$ in E2) in laying hens diet but only on carrot and paprika addition. The fatty acid composition of egg yolk is shown in Table 4. As it can be seen, with the addition of FCM in hen's diet, the content of total saturated fatty acids, SFA (C14:0, C16:0, C18:0) was significantly lower $(p<0.01)$ in the experimental treatments $\mathrm{E} 1(28.78 \%)$ and E2 (30.10\%) in comparison with the control treatments $\mathrm{C} 1(40.21 \%)$ and $\mathrm{C} 2$ $(38.97 \%)$, which is highly desirable concerning their negative effects on human health. This reduction of SFA in egg yolk can be explained by the reduction of palmitic acid, which is the major SFA. The content of other SFA was not significantly different $(p>0.05)$, except for stearic acid in the experimental treatment $\mathrm{E} 1$ in comparison with $\mathrm{C} 1$ and $\mathrm{C} 2$. These results are in accordance with previous research data (Baucells et al., 2000; Kralik et al., 2008; Oliveira et al., 2010; Mattioli et al., 2017). However, the addition of FCM in hen's diet resulted in a significant increase $(p<0.001)$ in the content of total monounsaturated fatty acids, MUFAs (C18:1) and polyunsaturated fatty acids, PUFAs (C18:2 $\omega-6$, $\mathrm{C} 18: 3 \omega-3, \mathrm{C} 20: 5 \omega-3$ and $\mathrm{C} 22: 6 \omega-3)$ in egg yolks. 
Table 2.

Effect of dietary inclusion of FCM on egg quality after 30 days of feeding

\begin{tabular}{lcccc} 
Physical properties & C1 & C2 & E1 & E2 \\
\hline Egg weight, (g) & $66.50 \pm 4.5^{\mathrm{a}}$ & $67.55 \pm 4.6^{\mathrm{a}}$ & $66.48 \pm 3.2^{\mathrm{a}}$ & $64.17 \pm 6.7^{\mathrm{a}}$ \\
Yolk weight, (g) & $17.59 \pm 2.1^{\mathrm{a}}$ & $16.81 \pm 0.7^{\mathrm{a}}$ & $16.58 \pm 1.0^{\mathrm{a}}$ & $16.12 \pm 2.3^{\mathrm{a}}$ \\
Albumen weight,(g) & $43.26 \pm 1.9^{\mathrm{a}}$ & $44.04 \pm 4.3^{\mathrm{a}}$ & $44.03 \pm 3.9^{\mathrm{a}}$ & $46.08 \pm 2.2^{\mathrm{a}}$ \\
Shell weight, (g) & $7.45 \pm 0.8^{\mathrm{a}}$ & $7.82 \pm 0.9^{\mathrm{a}}$ & $6.76 \pm 0.6^{\mathrm{a}}$ & $6.86 \pm 0.7^{\mathrm{a}}$ \\
Shell thickness, (mm) & $0.34 \pm 0.55^{\mathrm{a}}$ & $0.35 \pm 0.07^{\mathrm{a}}$ & $0.34 \pm 0.04^{\mathrm{a}}$ & $0.33 \pm 0.05^{\mathrm{a}}$ \\
Yolk index & $40.92 \pm 2.3^{\mathrm{a}}$ & $44.76 \pm 3.0^{\mathrm{a}}$ & $40.91 \pm 2.0^{\mathrm{a}}$ & $44.23 \pm 3.7^{\mathrm{a}}$ \\
Yolk pH & $6.04 \pm 0.01^{\mathrm{a}}$ & $6.02 \pm 0.01^{\mathrm{a}}$ & $6.01 \pm 0.03^{\mathrm{a}}$ & $6.04 \pm 0.07^{\mathrm{a}}$ \\
Albumen pH & $8.86 \pm 0.06^{\mathrm{a}}$ & $8.82 \pm 0.04^{\mathrm{a}}$ & $8.71 \pm 0.10^{\mathrm{a}}$ & $8.69 \pm 0.11^{\mathrm{a}}$ \\
\hline aldentical superscript letters within a row indicate no significant difference between means in observed data (at \\
p>0.05 level); \\
C1 and C2- control treatments, E1 and E2 - experimental treatments & &
\end{tabular}

Table 3.

Effect of dietary inclusion of FCM, carrot and paprika on yolk colour after 30 days of feeding

\begin{tabular}{lcccc}
\hline Variable & C1 & C2 & E1 & E2 \\
\hline$L^{*}$ & $51.47 \pm 1.7^{\mathrm{a}}$ & $48.81 \pm 1.7^{\mathrm{a}}$ & $50.21 \pm 2.3^{\mathrm{a}}$ & $49.42 \pm 2.5^{\mathrm{a}}$ \\
$a^{*}$ & $0.56 \pm 0.8^{\mathrm{a}}$ & $13.32 \pm 0.7^{\mathrm{c}}$ & $9.96 \pm 1.6^{\mathrm{b}}$ & $10.26 \pm 2.0^{\mathrm{b}}$ \\
$b^{*}$ & $38.08 \pm 3.2^{\mathrm{a}}$ & $36.20 \pm 3.8^{\mathrm{a}}$ & $38.64 \pm 2.5^{\mathrm{a}}$ & $37.69 \pm 4.8^{\mathrm{a}}$ \\
$\beta$-carotene $(\mu \mathrm{g} / \mathrm{g})$ & $29.97 \pm 0.4^{\mathrm{a}}$ & $55.15 \pm 3.3^{\mathrm{b}}$ & $50.09 \pm 5.0^{\mathrm{b}}$ & $49.25 \pm 3.3^{\mathrm{b}}$ \\
RYCF & $8.28 \pm 0.9^{\mathrm{a}}$ & $14.17 \pm 0.7^{\mathrm{c}}$ & $12.78 \pm 0.7^{\mathrm{b}}$ & $12.78 \pm 0.7^{\mathrm{b}}$ \\
\hline a-c Different superscript letters in a row indicate significantly different means in observed data (at $p<0.05$ level); \\
C1 and C2- control treatments, E1 and E2 - experimental treatments
\end{tabular}

Table 4.

Content of fatty acids in egg yolk after 30 days of the feeding

\begin{tabular}{|c|c|c|c|c|}
\hline Fatty acid & C1 & C2 & E1 & E2 \\
\hline C14:0 & $0.31 \pm 0.02^{a}$ & $0.27 \pm 0.02^{\mathrm{a}}$ & $0.27 \pm 0.04^{\mathrm{a}}$ & $0.22 \pm 0.02^{a}$ \\
\hline C16:0 & $28.26 \pm 0.22^{b}$ & $26.79 \pm 0.26^{b}$ & $20.12 \pm 1.64^{a}$ & $19.55 \pm 0.20^{a}$ \\
\hline C18:0 & $11.07 \pm 0.11^{b}$ & $11.46 \pm 0.22^{b}$ & $8.27 \pm 1.71^{a}$ & $10.14 \pm 2.01^{\mathrm{ab}}$ \\
\hline C18:1w-9 & $42.12 \pm 1.30^{\mathrm{a}}$ & $41.85 \pm 1.16^{a}$ & $47.32 \pm 0.88^{b}$ & $44.96 \pm 0.53^{b}$ \\
\hline C18:2w-6 & $13.19 \pm 0.74^{a}$ & $14.90 \pm 1.14^{a}$ & $12.28 \pm 2.02^{\mathrm{a}}$ & $11.25 \pm 1.84^{\mathrm{a}}$ \\
\hline$C 18: 3 \omega-3$ & $0.77 \pm 0.08^{a}$ & $0.98 \pm 0.11^{a}$ & $6.46 \pm 0.35^{b}$ & $8.87 \pm 0.26^{b}$ \\
\hline$C 20: 5 \omega-3$ & $0.03 \pm 0.01^{a}$ & $0.04 \pm 0.01^{a}$ & $0.17 \pm 0.05^{\mathrm{b}}$ & $0.21 \pm 0.02^{b}$ \\
\hline$C 22: 6 \omega-3$ & $0.62 \pm 0.11^{a}$ & $0.69 \pm 0.08^{\mathrm{a}}$ & $2.01 \pm 0.36^{b}$ & $2.08 \pm 0.05^{b}$ \\
\hline SFA & $40.21 \pm 0.19^{b}$ & $38.97 \pm 0.28^{b}$ & $28.78 \pm 3.35^{\mathrm{a}}$ & $30.10 \pm 2.34^{\mathrm{a}}$ \\
\hline MUFA & $44.91 \pm 1.14^{\mathrm{ab}}$ & $43.97 \pm 1.02^{\mathrm{a}}$ & $50.20 \pm 1.39^{c}$ & $47.25 \pm 0.47^{b}$ \\
\hline PUFA & $14.87 \pm 0.95^{a}$ & $17.00 \pm 0.83^{a}$ & $21.02 \pm 1.96^{b}$ & $22.50 \pm 2.07^{b}$ \\
\hline$\sum \omega-6$ & $13.33 \pm 0.75^{a}$ & $15.04 \pm 1.14^{a}$ & $12.38 \pm 1.43^{\mathrm{a}}$ & $11.30 \pm 1.35^{a}$ \\
\hline$\sum \omega-3$ & $1.42 \pm 0.18^{a}$ & $1.71 \pm 0.20^{\mathrm{a}}$ & $8.64 \pm 0.04^{b}$ & $11.15 \pm 0.16^{c}$ \\
\hline$\omega-6 / \omega-3$ & $9.40 \pm 0.69^{b}$ & $8.88 \pm 1.69^{b}$ & $1.43 \pm 0.17^{\mathrm{a}}$ & $1.01 \pm 0.11^{\mathrm{a}}$ \\
\hline
\end{tabular}

${ }^{a-c}$ Different superscript letters in a row show significantly different means in observed data (at $p<0.05$ level); $C 1$ and C2- control treatments, E1 and E2 - experimental treatments; SFA - saturated fatty acid;

MUFA - monounsaturated fatty acids; PUFA - polyunsaturated fatty acids 


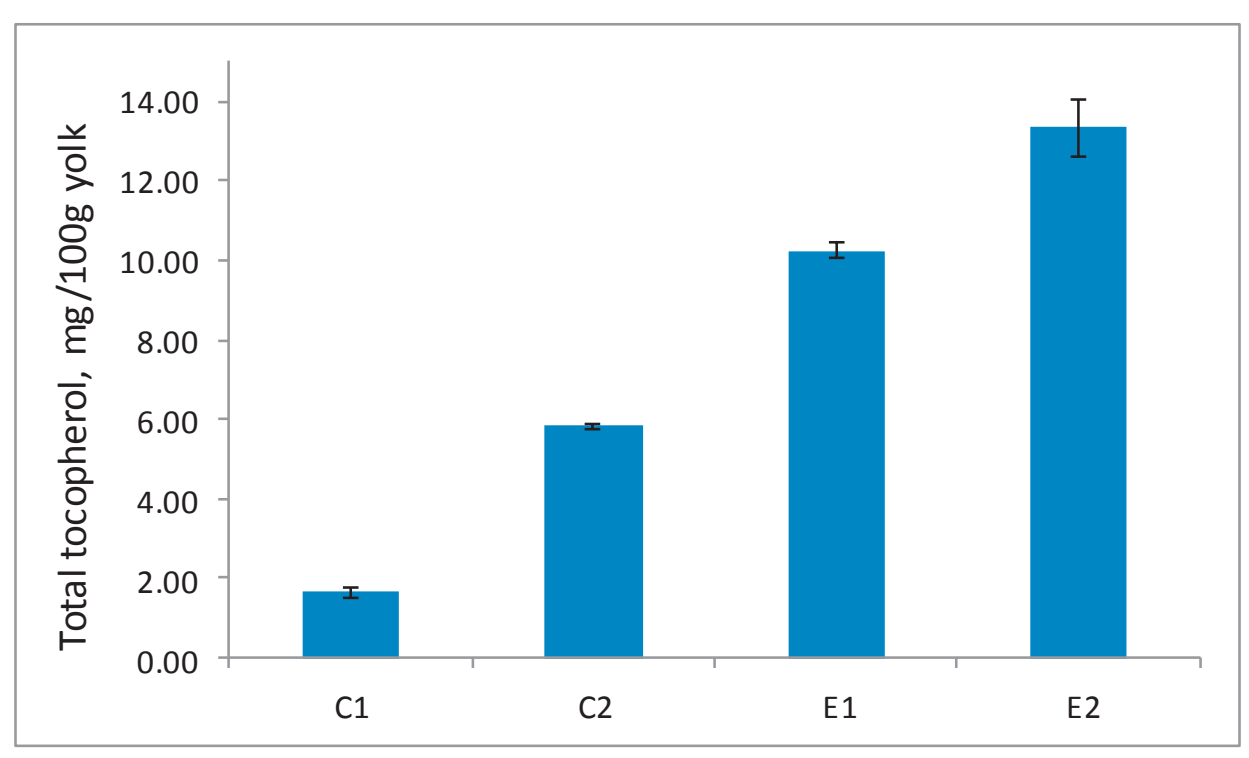

Figure 1. Content of total tocopherols in egg yolks of laying hens

(C1 and C2- control treatments, E1 and E2 - experimental treatments)

The content of almost all individual PUFAs was significantly higher $(p<0.001)$ in yolks from the experimental treatments, except for the content of linoleic acid (LA), which was significantly lower $(p<0.001)$ in yolks from the experimental treatments $E 1$ $(12.28 \%)$ and E2 $(11.25 \%)$ compared to the control treatments $\mathrm{C} 1(13.19 \%)$ and C2 (14.90\%). The results are in compliance with previous studies (Aymond and Van Elswyk, 1995; Grobas et al., 2001; Mattioli et al., 2017).

Reduction of linoleic acid content in egg yolks has been one of the aims of this study. Higher amount of $\omega-6$ fatty acids is not desirable because these FA are involved in competition for enzymes. This competition reduces the efficiency of ALA conversion into EPA and DHA as the ratio of LA/ALA increases (Fraeye et al., 2012).

The addition of flax co-extrudates into the hens' diet resulted in a significant increase $(p<0.001)$ in the content of desirable $\omega-3$ fatty acids (ALA, EPA and DHA) in egg yolks. After 30 days of feeding trial, the content of $\alpha$-linolenic acid in yolks from the experimental treatment $\mathrm{E} 1$ (with the share of co-extrudates in the diet at $13.50 \%$ ) was $6.46 \%$, which is 8.4 times higher than that in the control treatment $\mathrm{C} 1(0.77 \%)$ as well as 6.6 times more than that in the control treatment C2 $(0.98 \%)$. The level of $\alpha$-linolenic acid in the experimental treatment E2 (share of co-extrudates in the diet at $22.50 \%$ ) was found to be $8.87 \%$, which is 11.5 and 9 times higher in comparison to the control treatments $\mathrm{C} 1$ and $\mathrm{C} 2$, respectively. The same trend was observed in other studies (Hayat et al., 2009; Nain et al., 2012; Coorey et al., 2015; Lemahieu et al., 2015).

However, as Simopoulos (2009) stated, the critical fatty acid efficiency factor is not the absolute amount of omega- 6 and omega- 3 fatty acids but their ratio. This ratio is more favourable when it approaches $1: 1$ ratio. The ratio of $\omega-6 / \omega-3$ fatty acids being less than $4: 1$ increases the conversion rate of EPA and DHA from ALA (Simopoulos, 2001). The $\omega-6 / \omega-3$ ratio was significantly lower $(p<0.001)$ in the experimental treatments E1 (1.43) and E2 (1.01) than in the control treatments $C 1$ (9.40) and C2 (8.88). This ratio was below 2 which is a lower value in comparison to the $\omega-6 / \omega-3$ ratio reported in previously published studies where addition of flaxseed or its products in laying hens diet was investigated (Shapira et al., 2008; Nain et al., 2012; Aziza et al., 2013).

As already stated, flaxseed is very sensitive to oxidation and polymerization after the thermal process, and therefore, needs to be protected with the addition of antioxidants such as vitamin E (Tepe et al. 2005, Kulisić et al. 2004). As shown in 
Figure 1, the content of tocopherols linearly increased in egg yolk with an increase in FMC in the diet of laying hens.

Total tocopherol content was significantly higher $(p<0.05)$ in yolks from the experimental treatments E2 (with 5\% fat) compared to the experimental treatments E1 where hens were fed $3 \%$ fat. The increment in the content of tocopherols was expected since these vitamins are soluble in fats and they increase with a share of FCM in the diet. The content of tocopherols was 6-fold higher in yolks from the experimental treatment $\mathrm{E} 1$ than that from the control treatment $\mathrm{C} 1$ and 1.8-fold higher than that from the control treatment $\mathrm{C} 2$. The content of tocopherols was 8 times higher in yolks from the experimental treatment E2 as compared to the control treatment $\mathrm{C} 1$ i.e. 2.3 times higher than the control treatment C2. These results are in accordance with Hayat et al. (2010). According to Hayat et al. (2009), consuming 2 eggs from laying hens fed with flaxseed supplemented with $150 \mathrm{UI}$ of tocopherol, can provide $11 \mathrm{mg}$ of tocopherol in human nutrition, which represents the recommended daily intake of this vitamin.

\section{CONCLUSIONS}

The inclusion of flax co-extrudates into the hens' diet did not negatively affect any of the egg quality parameters. FCM in combination with the addition of natural pigments ( $1 \%$ carrot and $0.5 \%$ paprika) gave the desired value of yolk colour of 12.78 according RYCF. The addition of functional product FCM in hen's diet significantly decreased the content of saturated and increased the content of desired ALA, EPA and DHA, as well as tocopherols in the experimental treatments in comparison with control treatments. Concerning the current trends and consumer demands for balanced and healthy foods, it can be concluded that functional eggs enriched with flaxseed products as a source of $\omega-3$ fatty acids and natural pigments as colouring agents are ideal food. Eggs enriched with natural pigments, $\omega-3$ fatty acids and tocopherols can be produced with minor changes in the diet of laying hens without adversely affecting the production and technological parameters of egg quality.

\section{ACKNOWLEDGEMENTS}

The paper is a part of the research work on the project III46012 funded by the Ministry of Education, Science and Technological Development of the Republic of Serbia.

\section{REFERENCES}

1. Ahmad, S., Ahsan-ul-Haq, Yousaf, M., Kamran, Z., Ata-ur-Rehman, Sohail, M., Shahid-ur-Rahman (2013). Effect of feeding whole linseed as a source of polyunsaturated fatty acids on performance and egg characteristics of laying hens kept at high ambient temperature. Brazilian Journal of Poultry Science, 15, 21-26.

2. AOAC (1998). Association of Analytical Communities. Official Methods of Analysis (16th ed.). Gaithersburg, MD, USA.

3. Aymond, W.M., Van Elswyk, M.E. (1995). Yolk thiobarbituric acid reactive substances and $n-3$ fatty acids in response to whole and ground flaxseed. Poultry Science, 74, 1388-1394.

4. Aziza, A.E., Panda, A.K., Quezada, N., Cherian, G. (2013). Nutrient digestibility, egg quality, and fatty acid composition of brown laying hens fed camelina or flaxseed meal. The Journal of Applied Poultry Research, 22, 832-841.

5. Baucells, M.D., Crespo, N., Barroeta, A.C., López-Ferrer, S., Grashorn, M.A. (2000). Incorporation of different polyunsaturated fatty acids into eggs. Poultry Science, 79, 51-59.

6. Bean, D., Leeson, S. (2003). Long-term effects of feeding flaxseed on performance and egg fatty acid composition of brown and white hens. Poultry Science, 82, 388-394.

7. Cherian, G., Quezada, N. (2016). Egg quality, fatty acid composition and immunoglobulin $Y$ content in eggs from laying hens fed full fat camelina or flax seed. Journal of Animal Science and Biotechnology, 7, 15.

8. Čolović, D., Lević, J., Čabarkapa, I., Čolović, R., Lević, L., Sedej, I. (2015) Stability of an extruded, linseed-based functional feed additive with the supplementation of vitamin $\mathrm{E}$ and carvacrol. Journal of Animal and Feed Sciences, 24, 348-357.

9. Coorey, R., Novinda, A., Williams, H., Jayasena, V. (2015). Omega-3 fatty acid profile of eggs from laying hens fed diets supplemented with chia, fish oil, and flaxseed. Journal of Food Science, 80, 180-187.

10. Folch, J., Lees, M., Sloane Stanley, G., (1957). A simple method for the isolation and purification of total lipids from animal tissues. Journal of Biological Chemistry, 226, 497-509.

11. Fraeye, I., Bruneel, C., Lemahieu, C., Buyse, J., Muylaert, K., Foubert, I. (2012). Dietary enrichment of eggs with omega-3 fatty acids: A review. Food Research International, 48, 961969. 
12. Grobas, S., Méndez, J., Lázaro, R., de Blas, C., Mateo, G.G. (2001). Influence of source and percentage of fat added to diet on performance and fatty acid composition of egg yolks of two strains of laying hens. Poultry Science, 80, 1171-1179.

13. Hayat, Z., Cherian, G., Pasha, T.N., Khattak, F.M., Jabbar, M.A. (2009). Effect of feeding flax and two types of antioxidants on egg production, egg quality, and lipid composition of eggs. The Journal of Applied Poultry Research, 18, 541-551.

14. Hayat, Z., Cherian, G., Pasha, T.N., Khattak, F.M., Jabbar, M.A. (2010). Oxidative stability and lipid components of eggs from flax-fed hens: Effect of dietary antioxidants and storage. Poultry Science, 89, 1285-1292.

15. Htoo, J., Meng, X., Patience, J., Dugan, M., Zijlstra, R. (2008). Effects of coextrusion of flaxseed and field pea on the digestibility of energy, ether extract, fatty acids, protein, and amino acids in grower-finisher pigs. Journal of Animal Science, 86, 2942-2951.

16. Ivanov, D., Colovic, R., Levic, J., Sredanovic, S. (2012). Optimization of supercritical fluid extraction of linseed oil using RSM. European Journal of Lipid Science and Technology, 114, 807-815.

17. Khan, R.U., Naz, S., Nikousefat, Z., Tufarelli, V., Javdani, M., Qureshi, M.S., Laudadio, V. (2012). Potential applications of ginger (Zingiber officinale) in poultry diets. World's Poultry Science Journal, 68, 245-252.

18. Kralik, G., Škrtić, Z., Suchý, P., Straková, E., Gajčević, Z. (2008). Feeding fish oil and linseed oil to laying hens to increase the n-3 PUFA in egg yolk. Acta Veterinaria Brno, 77, 561-568.

19. Kulisić, T., Radonić, A., Katalinić, V., Miloš M. (2004). Use of different methods for testing antioxidative activity of oregano essential oil. Food Chemistry, 85, 633-640.

20. Lemahieu, C., Bruneel, C., Ryckebosch, E., Muylaert, K., Buyse, J., Foubert, I. (2015). Impact of different omega-3 polyunsaturated fatty acid (n-3 PUFA) sources (flaxseed, Isochrysis galbana, fish oil and DHA Gold) on n-3 LCPUFA enrichment (efficiency) in the egg yolk. Journal of Functional Foods, 19, 821-827.

21. Lokaewmanee, K., Yamauchi, K., Komori, T., Saito, K. (2010). Effects on egg yolk colour of paprika or paprika combined with marigold flower extracts. Italian Journal of Animal Science, 9 (67), 356-359.

22. Mattioli, S., Ruggeri, S., Sebastiani, B., Brecchia, G., Dal Bosco, A., Cartoni Mancinelli, A., Castellini, C. (2017). Performance and egg quality of laying hens fed flaxseed: highlights on n-3 fatty acids, cholesterol, lignans and isoflavones. Animal, 11, 705-712.

23. Nain, S., Renema, R.A., Korver, D.R., Zuidhof, M.J. (2012). Characterization of the n-3 polyunsaturated fatty acid enrichment in laying hens fed an extruded flax enrichment source. Poultry Science, 91, 1720-1732.

24. Oliveira, D.D., Baião, N.C., Cançado, S.V., Grimaldi, R., Souza, M.R., Lara, L.J.C., Lana, A.M.Q. (2010). Effects of lipid sources in the diet of laying hens on the fatty acid profiles of egg yolks. Poultry Science, 89, 2484-2490.

25. Rabrenović, B.B., Vujasinović, V.B., Novaković, M.M., Čorbo, S.Č., Basić, Z.N. (2016). Uporedni prikaz nutritivne vrednosti hladno presovanih ulja semena tikve (Cucurbita pepo L.) različitog porekla. Hemijska Industrija, 70, 5965.

26. Rowghani, E., Maddahian, A., Abousadi, M.A. (2006). Effects of addition of marigold flower, safflower petals, and red pepper on egg-yolk color and egg production in laying hens. $\mathrm{Pa}$ kistan Journal of Biological Sciences, 9 (7), 1333-1337.

27. Shapira, N., Weill, P., Loewenbach R. (2008). Egg fortification with $n-3$ polyunsaturated fatty acids (PUFA): nutritional benefits versus high $\mathrm{n}$ 6 PUFA western diets, and consumer acceptance. IMAJ, 10, 262-265.

28. Sierra, S., Lara-Villoslada, F., Comalada, M., Olivares, M., Xaus, J. (2008). Dietary eicosapentaenoic acid and docosahexaenoic acid equally incorporate as decosahexaenoic acid but differ in inflammatory effects. Nutrition, 24, $245-254$.

29. Simopoulos, A.P. (2000). Human requirement for n-3 polyunsaturated fatty acids. Poultry Science, 79, 961-970.

30. Simopoulos, A.P. (2001). Evolutionary aspects of diet, essential fatty acids and cardiovascular disease. European Heart Journal Supplements, 3, 8-21.

31. Simopoulos, A.P. (2009). Evolutionary aspects of the dietary omega-6: omega-3 fatty acid ratio: medical implications. World Review of $\mathrm{Nu}$ trition and Dietetics, 100, 1-21.

32. Skrivan, M., Englmaierova, M. (2014). The deposition of carotenoids and a-tocopherol in hen eggs produced under a combination of sequential feeding and grazing. Animal Feed Science and Technology, 190, 79-86.

33. Spasevski, N., Puvača, N., Pezo, L., Tasić, T., Vukmirović, Đ., Banjac, V., Čolović, R., Rakita, S., Kokić, B., Džinić, N. (2018). Optimisation of egg yolk colour using natural colourants. European Poultry Science (Archiv für Geflügelkunde) 82, 1-17.

34. Spasevski, N., Čolović, D., Rakita, S., Ikonić, P., Đuragić, O., Banjac, V., Vukmirović, Đ. (2016). Fatty acid composition and $\beta$-carotene content in egg yolk of laying hens fed with linseed, paprika and marigold. Contemporary Agriculture, 65 (1-2), 15-22.

35. Tepe, B., Sokmen, M., Akpulat, H.A., Daferera, D., Polissiou, M., Sokmen, A. (2005). Antioxidative activity of the essential oils of Thymus sipyleus subsp. sipyleus var. sipyleus and Thymus sipyleus subsp. sipyleus var. rosulans. Journal of Food Engineering, 66, 447-454.

36. Wang, C., Chung, M., Lichtenstein, A., Balk, E., Kupelnick, B., DeVine, D., Lawrence, A., Lau, J. (2004). Effects of omega-3 fatty acids on cardiovascular disease. Evidence Reports/Technology Assessments, 94, 1-8.

37. Whelan, J., Rust, C. (2006). Innovative dietary sources of n-3 fatty acids. Annual Review of Nutrition, 26, 75-103 


\section{ПРИРОДНИ АДИТИВИ У ПРОИЗВОДњИ ФУНКЦИОНАЛНИХ ЈАЈА}

Недељка Ј. Спасевски ${ }^{* 1}$, Татјана А. Пеулић ${ }^{1}$, Војислав В. Бањац ${ }^{1}$, Слађана М. Ракита ${ }^{1}$, Лато Л. Пезо ${ }^{2}$ Р Радмило Р. Чоловић ${ }^{1}$, Зорица Н. Басић ${ }^{3}$

${ }^{1}$ Универзитет у Новом Саду, Научни институт за прехрамбене технологије у Новом Саду, 21000 Нови Сад, Булевар цара Лазара бр. 1,

${ }^{2}$ Универзитет у Београду, Институт за општу и физичку хемију, 11158 Београд, Студентски трг $12 / \mathrm{V}$, Србија

${ }^{3}$ Војномедицинска академија, Институт за хигијену, 11040 Београд, Црнотравска 17, Србија

Сажетак: Конзумна јаја могу играти важну улогу као функционална храна ако се за њихову производњу користе посебно дизајниране смеше обогаћене $\omega-3$ масним киселинама, природним пигментима и витаминима. Дакле, циљ ове студије био је истражити ефекте укључивања коекструдата на бази ланеног семена у комбинацији са природним пигментима у исхрану кокоши носиља и испитивање њиховог утицаја на фризичка својства, боју жуманца и састав масних киселина јаја.

Сто двадесет Lohmann Brown кокоши носиља храњено је на бази кукурузно-сојиног оброка уз додатак коекструдата лана у различитим пропорцијама: 0\% (контролни K1 и K2), 13,50\% (E1) и $22,50 \%$ (E2). Контролни третман (K1) садржао је до 3\% масти, без додатих пигмената, док је контролни третман (K2) садржао до 5\% масти и синтетичке пигменте. Експериментални третмани Е1 и Е2 (са 3\% и 5\% масти) имали су исту количину природних пигмената (1\% шаргарепе и 0,5\% паприке). Код јаја из експерименталних третмана E1 и E2 нису примећене значајне промене $(p>0,05)$ у карактеристикама квалитета јаја у поређењу са контролним јајима. Пожељна боја жуманца од 12,78 по RYCF (Roche Yolk Colour Fan скала) постигнута је у оба експериментална третмана E1 и E2. Јаја од кокошки храњених са коекструдатом лана имала су значајно виши ниво $(p<0,001)$ a-линоленске $(6,46 \%$ за E1 и $8,87 \%$ за E2), докозахексаенске $(2,01 \%$ за Е1 и 2,08\% за Е2) и еикозапентаенске $(0,17 \%$ за E1 и 0,21\% за Е2) киселине него јаја из контролних третмана. Однос $\omega-6 / \omega-3$ од 1,43 и 1,01 у третманима E1 и E2, респективно, био је значајно нижи $(p<0,001)$ од односа $\omega-6 / \omega-3$ у контролним третманима K1 и K2 $(9,40$ и 8,88, редом). Садржај токоферола у јајима из експерименталних третмана E1 и E2 био је 6 и 8 пута већи него у јајима из контролног третмана $\mathrm{K} 1$, као и 1,8 и 2,3 пута већи него у јајима из контролног третмана K2, респективно. Додавањем коекструдата лана и природних пигмената у исхрану кокоши носиља могуће је произвести функционално јаје са пожељном бојом жуманца и саставом масних киселина.

Кључне речи: коекструдат лана, шаргарепа, паприка, полинезасићене масне киселине, однос $\omega-6 / \omega-3$, токофероли

Received: 29 October 2019

Received in revised form: 22 November 2019

Accepted: 5 December 2019 